\title{
Discurso proferido pelo professor ERNESTO LEME, em saudação aos membros do Congresso Nacional de Direito Judiciario, na sessão promovida em sua homenagem, a 22 de julho de 1936, pelo Instituto dos Advogados de São Paulo.
}

Senhores membros do Congresso Nacional de Direito Judiciario.

Os mais acerrimos adversarios da unidade do processo, consagrada, definitivamente, em nossa Carta Constitucional, hão de abençoar, nesta hora, a sua derrota. Dois annos decorreram. E, na Capital da Republica, por iniciativa do Instituto da Ordem dos Advogados Brasileiros, tão superiormente dirigido pela lucida inteligencia de Edmundo de Miranda Jordão, reune-se o primeiro Congresso Nacional de Direito Judiciario.

De todos os recantos do paiz, os juristas acorrem, solicitos, ao apelo fraterno. A tóga dos magistrados roçando pela béca dos professores, a erudição dos homens de gabinete em contacto com a experiencia dos praticos do fôro, numa obra de cultura e de civismo, que tanto vos enaltece, pudestes, ao termino de vosso trabalho, oferecer, ao poder legislativo, um abundante manancial de sugestões, que hão de orientá-lo com segurança, na feitura dos Codigos de processo, que lhe cabe elaborar.

Bem hajam os que tomaram a responsabilidade da convocação deste Congresso e o levaram ao esplendido triunfo, que hoje celebramos. Numa época de tantas dificuldades e tantas preocupações, quando a humanidade se agita, incer- 
ta dos rumos que a esperam, e vemos, no Brasil, gente do nosso sangue, o animo conturbado, pôr-se a soldo de governos estrangeiros, em criminosas investidas contra as instituições que nos regem, é confortador assistirmos a um espetaculo como esse, em que fostes parcela inestimavel, de se fundirem o devotamento dos moços e a sabedoria dos velhos, sob o patrocinio de um gremio de juristas, para traçar as regras da perfeita distribuição da Justiça, em todo paiz.

Antes de retornardes aos vossos lares, cumprida a vossa tarefa, deliberastes, num gesto fidalgo, que altamente nos penhóra, honrar a nossa Capital, com a vossa visita.

A cidade, que o zelo dos companheiros de Manoel de Paiva aqui plantou, no alto da colina, por certo vos agradou, no surto de progresso que a impele, cada vez mais alto, para gloria da nossa nacionalidade. Mas, talvez não seja esse o aspecto que mais vos terá seduzido. Viestes, principalmente, conhecer, ou rever a urbe magnifica, em que a 7 de setembro de 1822 se fez a nossa emancipação politica e em que, a 11 de agosto de 1827, com a creação de sua Academia de Direito, se fez a nossa emancipação cultural.

Já não encontrastes senão os restos do velho cenobio franciscano, onde gerações de estudantes se embeberam nos sãos principios do direito. As exigencias da vida moderna não respeitam a velha casa, em cujo local se vae erguendo o novo edificio da Faculdade. Emı uma de suas salas, que a veneração dos professores, consagrou á memoria de João Mendes Junior, é que o Instituto dos Advogados de São Paulo hoje vos recebe.

Nada vos poderia tocar tão fundamente o coração, como essa feliz coincidencia, que vos propicia o ensejo de receber, com os aplausos que nos merece a vossa obra, a bençam do insigne Mestre, que formou, na catedra de Direito Judiciario, da Faculdade de Direito, com Ramalho, João Monteiro, e Estevam de Almeida, a luminosa cohorte dos grandes processualistas de nossa terra. Mas, a lampada vitae, na corrida de archotes, de Lucrecio, ainda mantém bem viva a sua chama, passando das mãos do que tombou, 
examine, - "et quasi cursores vitae lampada tradunt", para o que véla hoje pela perenidade da flama. 0 professor Francisco Morato, que honra esta solenidade com a sua presença, sabe manter o facho da tradição, na cadeira de João Mendes e de Joaquim Ignacio Ramalho...

É com a mais justa ufania que o Instituto dos Advogados de São Paulo óra vos acolhe. Operarios do mesmo oficio, cultores do direito, como vós, não desconhecemos as responsabilidades que pesam sobre os nossos ombros, nos dias que correm. Amamos a nossa Patria e mais nos esmeramos, em meio ás dôres que a laceram, por melhor amá-la e servì-la. Jamais lhe faltarão, como nunca lhe faltaram, nos transes mais amargos por que passou, a solidariedade e o devotamento de toda a nação.

Se na propria Russia, onde o comunismo conseguiu implantar-se, pela surpreza e pela audacia, já não se mantém essa doutrina, em sua primitiva ortodoxia, não será no Brasil, paiz onde é irrisão falar-se em pão, terra e liberdade, na frase do proprio chefe de nossos inconscientes patricios, que tentam cavar a ruina da Patria, que similhante loucura poderia encontrar ambiente favoravel para viver.

Cabe-nos, a nós juristas, como condutores naturais, que a nossa profissão nos reserva, a missão de tomar, desde logo, nosso logar nas fileiras dos combatentes, para a guerra sem tréguas ao extremismo, visando extirpá-lo, como planta exotica, do sólo nacional. Sirvamo-nos de todas as oportunidades para a doutrinação sadia, para o ambiente fecundo e pertinaz. Que nada nos detenha. Digamos, como os antigos gaulezes: "Nós só tememos é que o céo desabe"... $\mathbf{E}$ o céu não desabará: a cruzada, em que nos empenhamos, é a propria salvaguarda do templo do Senhor.

Dahi a grande missão óra reservada aos Institutos de Advogados, como coordenadores dessas atividades e orientadores dessa campanha. Para ela não nos faltará o prestigioso apoio da magistratura, cujo concurso ainda agora se 
fez notar, tão eficazmente, no Congresso de Direito Judiciario e cuja missão, paralela á dos advogados, colima a mesma finalidade pela qual lutamos: o imperio da lei e da justiça.

Essa a grande tarefa para a qual o Instituto dos Advogados de São Paulo vos conclama, senhores congressistas. A vossa visita de hoje dá-nos o ensejo de falar, por vosso intermedio e com egual confiança, a todos os juristas do Brasil, que aqui tão dignamente representaes.

Sêde bemvindos a esta casa. E dizei, aos nossos irmãos dos outros Estados e da Capital Federal, que São Paulo está de pé, como sempre, guarda fiel da Constituição, pela qual se votou até mesmo ao sacrificio de seu sangue, em 1932. E, no momento em que os juristas do Brasil se congregam, para a feitura de seus Codigos de Processo, que vão lembrar-nos ainda mais, a identidade da nossa origem, os advogados paulistas vos estreitam ao coração e erguem um hino de fé, á grandeza da Patria comum! 